\title{
KOMPETENSI GURU IPS DALAM PEMBELAJARAN BERBASIS PEDIDIKAN KARAKTER DI SMP MUHAMMADIYAH KOTA TERNATE
}

\author{
Suardi Kader, Sugiharsono \\ SMA Negeri 4 Makian Barat Maluku Utara, Universitas Negeri Yogyakarta \\ irwanabubakar@yahoo.co.id
}

\begin{abstract}
Abstrak
Penelitian ini merupakan penelitian deskriptif kualitatif. Subjek penelitian terdiri atas: semua guru, kepala sekolah, dan siswa sebagai responden. Objek penelitian ini adalah kompetensi guru dalam menerapkan berbagai metode untuk pendidikan karakter pada pembelajaran IPS yang terintegrasi. Pengumpulan data dilakukan melalui wawancara, dokumentasi dan observasi. Teknik analisis data yang digunakan adalah teknik analisis kualitatif model induktif.

Hasil penelitian adalah sebagai berikut: (1) Kompetensi guru IPS dalam pedidikan karakter di SMP Muhammadiyah 1 dan 2 Kota Ternate belum memuaskan. Hal ini disebabkan oleh guru IPS masih kurang memiliki wawasan dasar keilmuan karakter. Di samping itu juga, guru belum aktif dan kreatif, serta memiliki kemampuan untuk mengembangkan wawasan pendidikan karakter ke dalam mata pelajaran IPS. (2) Metode pembelajaran IPS di SMP Muhammadiyah 1 dan SMP Muhammadiyah 2 Kota Ternate masih cenderung bersifat konvensional, yaitu ceramah. (3) Kendala-kendala yang ditemukan dalam pembelajaran pendidikan karakter di SMP Muhammadiyah 1 dan SMP Muhammadiyah 2 Kota Ternate yaitu berasal dari guru, sarana, dan prasarana yang belum memadai, lemahnya kesadaran peserta didik, dana dan pembiayaan yang masih kurang, program pembelajaran, pembinaan karakter karena masih kurangnya pemahaman dari pembina atau guru, serta buku-buku penunjang yang digunakan untuk kepentingan proses pembelajaran.
\end{abstract}

Kata kunci: kompetensi guru IPS, pembelajaran, dan pendidikan karakter

\section{SOCIAL STUDIES TEACHERS' COMPETENCES IN CHARACTER-EDUCATION-BASED TEACHING IN MUHAMMADIYAH JUNIOR HIGH SCHOOLS IN TERNATE CITY}

\author{
Suardi Kader, Sugiharsono \\ SMA Negeri 4 Makian Barat Maluku Utara, Universitas Negeri Yogyakarta \\ irwanabubakar@yahoo.co.id
}

\begin{abstract}
This was a qualitative descriptive study. The research subjects consisted of the teachers, principals, and students. The research object was the teachers' competencies in applying a variety of methods in character education integrated in Social Studies teaching. The data were collected through interviews, documentation, and observations. They were analyzed using the qualitative analysis technique of the inductive model.

The results of the study are as follows: (1) The Social Studies teachers' competencies in character education in SMP Muhammadiyah 1 and 2 Ternate City are not satisfactory. This is caused by their lack of basic insights into knowledge of character education. Besides, it is caused by their activities and capabilities to develop character education in Social Studies. (2) Their competencies in teaching character education are still low; this is caused by the fact that SMP Muhammadiyah 2 Ternate City still applies the lecturing method. (3) The constraints in the teaching of character education in SMP Muhammadiyah 1 and SMP Muhammadiyah 2 Ternate City come from the teachers, inadequate infrastucture facilities, students' education, inadequate funds, learning programs, character building, tutors' or teachers' lack of understanding, and lack of supporting books that are used for the purpose of learning the science itself.
\end{abstract}

Keywords: social studies teachers' competencies, learning, character education 


\section{Pendahuluan}

Kompetensi merupakan pengetahuan, keterampilan, sikap, dan nilai-nilai yang diwu-judkan dalam kebiasaan berpikir serta bertin-dak. Pengertian ini menegaskan bahwa kompe-tensi adalah kemampuan (pengetahuan, skills, sikap, dan nilai-nilai) yang diwujudkan dalam aktivitas berpikir dan berperilaku. Sedang menurut Undang-Undang Republik Indonesia No. 14 Tahun 2005 tentang Guru dan Dosen Pasal 1 menjelaskan bahwa kompetensi adalah seperangkat pengetahuan, ketrampilan, dan perilaku yang harus dimiliki, dihayati, dan dikuasai oleh guru atau dosen dalam melaksanakan tugas keprofesionalannya.

Kompetensi juga dapat diartikan sebagai perangkat perilaku efektif yang terkait dengan eksplorasi dan investigasi, menganalisis dan memikirkan, serta memberikan perhatian, dan mempersepsi yang mengarahkan seseorang menemukan cara-cara untuk mencapai tujuan tertentu secara efektif dan efisien (Mulyasa, 2012: 26). Kompetensi dalam hal ini dapat dihubungkan dengan skills yang berhasil dikuasai oleh seseorang sehingga ia dapat melakukan suatu tugas atau pekerjaan dengan baik dan berhasil. Karena itu, orientasi pengembangan kompetensi adalah dikuasainya berbagai macam life skills yang penting dan bermanfaat bagi hidup seserang baik di masa kini maupun masa depannya.

Sementara itu, dalam perspektif kebijakan pendidikan Nasional, pemerintah telah merumuskan empat kompetensi guru sebagaimana tercantum dalam Undang-Undang No. 14 Tahun 2005 tentang Guru dan Dosen Pasal 8 menjelaskan bahwa guru wajib memiliki kualifikasi akademik, kompetensi, sertifikat pendidikan, sehat jasmani dan rohani, serta memiliki kemampuan untuk mewujudkan tujuan pendidikan nasional". Lebih lanjut pada Pasal 10 ayat 1 menjelaskan bahwa kompetensi guru sebagaimana dimaksud dalam Pasal 8 meliputi kompetensi pedagogik, kompetensi kepribadian, komptensi sosial, dan kempetensi profesional yang diperoleh melalui pendidikan profesi. Selanjutnya Martinis Yamin (2005: 131) menjelaskan bahwa rumusan kompetensi guru yang mempengaruhi kinerja guru dalam proses pembelajaran, yaitu: (1) menguasai bidang studi atau bahan ajaran, (2) memahami karakteristik peserta didik, (3) menguasai pengelolaan pembelajaran, (4) menguasai metode dan strategi pembelajaran, (5) menguasai penilaian hasil belajar siswa, (6) menguasai dan pengelolaan kelas, (7) menguasai penggunaan media atau sumber pembelajaran, (8) menguasai interaksi pembelajaran.

Untuk meningkatkan kualitas pendidikan Nasional pemerintah berusaha meningkatkan kualiatas guru. Berbagai upaya pemerintah dengan melakukan berbagai perubahan dan pembaharuan sistim pendidikan. Salah Salah satu upaya yang ditempuh pemerintah, yaitu dengan melakukan uji kompetensi guru. Melalui uji kompetensi guru diharapkan dapat menghasilkan guru benarbenar profesional sehingga dengan demikian dapat memwujudkan tujuan pendidikan nasional, yaitu mengembangkan kemampuan dan membantu watak serta peradaban bangsa bermartabat dalam rangka mencerdaskan kehidupan bangsa, bertujuan untuk berkembangnya potensi siswa agar menjadi manusia yang beriman dan bertakwa kepada Tuhan Yang Maha Esa, berakhlak mulia, sehat, berilmu, cakap, kreatif, mandiri, dan menjadi warga negara yang demokratis serta bertanggung jawab (Undang-Undang Sistem Pendidikan Nasional Nomor 20 Tahun 2003 Pasal 3).

Sistem pendidikan nasional ini mempunyai tujuan untuk menghasilkan kualitas yang cerdas dan berakhlak mulia adalah yang bersifat humanis dan memposisikan peserta didik sebagai pribadi dan sekaligus sebagai anggota masyarakat yang perlu dibantu dan didorong agar memiliki kebiasaan efektif, perpaduan antara keinginan, pengetahuan, dan keterampilan. Menurut Darmiyati Zuchdi (2009: 6) perpaduan tersebut secara harmonis menyebabkan seseorang atau suatu kelompok meninggalkan ketergantungan menuju kemandirian dan saling ketergantungan. Saling ketergantungan sangat diperlukan dalam kehidupan yang semakin kompleks dan hanya diatasi secara kolaboratif sehingga diperlukan keterampilan membangun hubungan yang serasi.

Anak-anak akan tumbuh menjadi pribadi yang berkarakter baik apabila dapat tumbuh dalam lingkungan sosial yang berkarakter dan memerlukan kesadaran dari seluruh pihak yang mempengaruhi kehidupan anak yaitu keluarga, sekolah, dan masyarakat. Sekolah sebagai salah satu pihak yang bertanggung jawab atas 
pendidikan karakter anak harus segera mengaplikasikan pendidikan karakter. Setelah memutuskan untuk menerapkan pendidikan karakter, sekolah berarti sudah mengambil komitmen yang memerlukan upaya dari seluruh warga sekolah khususnya kepala sekolah dan guru sesuai dengan tujuan pendidikan nasional.

Jadi sekolah selain mengajarkan pengetahuan juga harus mengajarkan kebaikan untuk membentuk peserta didik yang berkarakter. Pendidikan karakter mempunyai tiga bagian yang saling berhubungan yaitu moral knowing, moral feeling, dan moral behavior. Pendidikan karakter seharusnya dilaksanakan dengan pendekatan secara komprehensif yang meliputi inkulkasi nilai, keteladanan nilai, fasilitasi nilai, dan pengembangan keterampilan. Keteladanan nilai merupakan pemberian teladan oleh guru. Guru mempunyai peran yang sangat penting untuk memberikan model yang ideal dan memfasilitasi anak dalam pemerolehan pendidikan karakter. Oleh sebab itu, guru adalah contoh nyata yang bisa ditiru oleh murid. Selain contoh dalam pembelajaran yang dilakukan, guru haruslah mempunyai cara-cara yang bagus atau metode pembelajaran yang tepat dalam kegiatan belajar mengajar di sekolah, sehingga anak bisa mengadopsi nilai-nilai yang terkandung dalam proses pembelajaran yang dengan sengaja diberikan agar siswa menjadi lebih baik.

Tindakan anak-anak tersebut sebagaimana disampaikan oleh Piaget (Darmiyati Zuchdi; 2009: 12) pada usia 4 dan 5 tahun, anak-anak cenderung memperhatikan aturan-aturan yang dicontohkan oleh orang-orang yang lebih dewasa, kendati pada usia-usia ini anak-anak juga cenderung melanggar aturan-aturan tersebut. Pada usiausia berikutnya, antara 10 sampai 11 tahun, aturan-aturan permainan dianggap sebagai hukum yang dihasilkan dari kesepakatan bersama, kendati mereka melihat aturan tersebut sebagai sesuatu yang dapat saja dimodifikasi. Konsepsi anak mengenai aturan pada dasarnya tidak hanya terbatas kepada sesuatu yang dianggap berubahubah pada dua tahapan yang berbeda, yaitu antara tahap realisme moral dan independensi moral.

Menurut Mochtar Buchori (2007), pendidikan karakter seharusnya membawa peserta didik ke pengenalan nilai secara kognitif, penghayatan nilai secara afektif, dan akhirnya kepengamalan nilai secara nyata. Permasalahan pendidikan karakter yang selama ini ada di SMP perlu segera dikaji, dan dicari altenatif-alternatif solusinya, serta perlu dikembangkannya secara lebih operasional sehingga mudah diimplementasikan di sekolah.

Zuchdi; 2009: 12) pada usia 4 dan 5 tahun, anak-anak cenderung memperhatikan aturanaturan yang dicontohkan oleh orang-orang yang lebih dewasa, kendati pada usia-usia ini anakanak juga cenderung melanggar aturan-aturan tersebut. Pada usia-usia berikutnya, antara 10 sampai 11 tahun, aturan-aturan permainan dianggap sebagai hukum yang dihasilkan dari kesepakatan bersama, kendati mereka melihat aturan tersebut sebagai sesuatu yang dapat saja dimodifikasi. Konsepsi anak mengenai aturan pada dasarnya tidak hanya terbatas kepada sesuatu yang dianggap berubah-ubah pada dua tahapan yang berbeda, yaitu antara tahap realisme moral dan independensi moral.

Dalam penanaman nilai-nilai karakter, guru harus mengantisipasi dan menghindari suasana kelas yang bernuansa persaingan atau kompetisi. Suasana kelas yang bersifat kompetisi atau persaingan akan merugikan sebagian siswa yang mempunyai kemampuan dalam berfikir lebih lambat dibandingkan teman-temannya yang lain dalam kelas tersebut. Hal ini karena dalam kelas tersebut siswa cenderung individualis dan akan bersaing untuk memperoleh nilai yang bagus dan mendapatkan pujian dari guru dengan menghalalkan berbagai cara.

Siswa yang tidak dapat bersaing dan berprestasi rendah mendapatkan umpan balik yang negatif dalam usaha-usaha akademis, mereka akan disepelekan. Hal ini dapat menurunkan motivasi belajar mereka. Seharusnya suasana belajar di kelas bersifat gotong royong. Peserta didik termotivasi untuk saling membantu dalam belajar dan saling mendorong satu sama lain untuk meraih kesuksesan dalam belajar yaitu siswa mampu memahami, menguasai dan mengaplikasikan pengetahuan dan nilai-nilai karakter yang diajarkan oleh guru.

Guru selayaknya mampu menggunakkan metode pembelajaran karakter terpadu. Untuk itu, guru harus mampu merencanakan dan memberikan kegiatan pembelajaran yang memotivasi dan menyenangkan siswa. Kegiatan pembelajaran 
pendidikan karakter yang dirancang tentu saja harus memperhatikan kondisi kompetensi guru itu sendiri serta faktor lingkungan yang meliputi sekolah dan masyarakat. Apabila siswa merasa termotivasi dan senang mengikuti pembelajaran karakter, maka pada akhirnya kemampuan guru dalam mengelolah pembelajaran yang diharapkan dikuasai dan dapat tercapai secara optimal.

Kompetensi guru IPS menerapkan pembelajaran karakter sangat berpengaruh terhadap kebermaknaan pengalaman bagi para peserta didik. Pengalaman belajar dalam kaitannya dengan unsur-unsur konseptual menjadikan proses pembelajaran lebih efektif. Kaitan konseptual yang dipelajari dengan sisi bidang kajian yang relevan akan membentuk skema (konsep) pembelajaran karakter, sehingga peserta didik akan memperoleh keutuhan dan pengetahuan. Perolehan keutuhan belajar, pengetahuan, kebulatan pandangan tentang kehidupan dan dapat direfleksikan melalui pembelajaran karakter.

Secara umum guru IPS di SMP Muhammadiyah 1 dan SMP Muhammadiyah 2 Kota Ternate sudah mengimplementasikan pembelajaran pendidikan karakter pada siswa di sekolah. Hasil obeservasi menunjukkan 1) Guru IPS mengalami kesulitan dalam menentukan dan memilih model yang sesuai dengan materi yang akan dibelajarkan serta sesuai dengan lingkungan masing-masing dan bagaimana menerapkannya dengan baik. Akibatnya guru tetap melakukan sesuai dengan kemampuannya. 2) Pembelajaran pendidikan karakter belum terlaksana maksimal. Hal ini disebabkan karena pengintegrasian nilai-nilai karakter dilakukan hanya terbatas pada mata pelajaran tertentu saja. 3) Proses pembelajaran yang terjadi masih fokus pada ranah kognitif siswa saja. 4) Dalam proses pembelajaran guru terpaku pada text book, sehingga penggunaan sumber belajar kurang bervariasi dan pembelajaran yang terjadi kurang menyentuh pengalaman dan kebutuhan siswa sehari-hari sehingga para guru IPS kurang menarik perhatian siswa. 5) Motivasi belajar siswa di SMP Muhammadiyah 1 dan SMP Muhammadiyah 2 Kota Ternate juga masih rendah. 6) Siswa kurang fokus dalam proses pembelajaran, 7) Siswa sibuk sendiri tanpa memperhatikan penjelasan guru. 8) Siswa juga sering mengeluh ketika diberi tugas oleh Guru.

\section{Metode Penelitian}

Jenis Penelitian

Dalam penelitian kualitatif terdapat beberapa teknik pengumpulan data yaitu observasi partisipan, wawancara secara mendalam, studi dokumentasi, dan pendekatan triaggulasi. Berikut teknik pengumpulan data, yaitu: observasi, wawancara, dokumen, catatan lapangan, dan lain-lain.

\section{Tempat dan Waktu Penelitian}

Lokasi atau tempat penelitian ini dilakukan yaitu di SMP Muhammadiyah 1 dan 2 Kota Ternate. Mengambil di sekolah ini sebagai tempat melakukan penelitian dengan alasan bahwa sekolah tersebut tidak jauh dari tempat tinggal dan pertimbangan bahwa penerapan pendidikan karakter sudah ada petunjuk dari dinas pendidikan Kota Ternate. Adapun waktu penelitian ini dilakukan selama tiga bulan, mulai bulan Januari 2012 sampai selesai sekitar bulan Mei 2012.

\section{Subjek dan Objek Penelitian}

Subjek penelitian yang dimaksud adalah orang yang mengetahui informasi permasalahan penelitian yaitu guru, kepala sekolah, dan siswa. Oleh karena itu, memfokuskan pada semua warga di lingkungan sekolah. Sedangkan objek penelitian ini adalah kompetensi guru IPS dalam pembelajaran pendidikan karakter dan penerapan metode pembelajaran.

Teknik Pengumpulan Data

Dalam penelitian kualitatif terdapat beberapa teknik pengumpulan data yaitu observasi partisipan, wawancara secara mendalam, studi dokumentasi, dan pendekatan triaggulasi. Berikut teknik pengumpulan data, yaitu: observasi, wawancara, dokumen, catatan lapangan, dan lain-lain.

Pengumpulan data di lokasi penelitian ini adalah sebagai berikut: (1) melakukan pendekatan secara informal di SMP Muhammadiyah1 dan SMP Muhammadiyah 2 Kota Ternate yaitu untuk menemui kepala sekolah, guru, dan staf administrasi terlebih dahulu, memperkenalkan diri serta mengutarakan maksud dan tujuan melaksanakan penelitian di SMP Muhammadiyah1 dan SMP Muhammadiyah 2 Kota Ternate yang berkaitan dengan kompetensi guru IPS dalam 
pembelajaran pendidikan karakter, (2) tahap berikutnya adalah terlebih dahulu melakukan pendekatan secara formal, untuk menyampaikan maksud kedatangan penelitian. Pendekatan secara formal ini disertai izin resmi, sehingga betul-betul dapat diterima di sekolah ini. Setelah menyampaikan izin secara formal, langkah selanjutnya melakukan pendekatan dengan responden yang akan dijadikan informan dengan terlebih dahulu berkonsultasi kepada kepala sekolah, (3) melibatkan diri secara aktif dalam proses pembelajaran di sekolah, dan difokuskan penelitian di kelas.

Teknik pengumpulan data yang digunakan dalam penelitian ini dilakukan melalui tiga cara yaitu teknik observasi, teknik wawancara, dan teknik dokumentasi. Untuk lebih jelasnya mengenai ketiga teknik tersebut di bawah ini.

Observasi menempati posisi sentral dengan mengoptimalkan peran kemampuan peneliti untuk melihat objek penelitian dalam menangkap arti fenomena di lapangan, observasi ini dilakukan secara langsung dan parsitipatif. Observasi yang dilakukan adalah mengamati proses belajar mengajar di kelas VII, VIII, dan IX dari awal sampai akhir dengan di foto untuk mengetahui kreatifitas guru dalam pembelajaran IPS terpadu.

wawancara dilakukan berdasarkan data awal yang dimiliki oleh peneliti melalui prasurvey. Selanjutnya peneliti menggambarkan sesuai dengan teori dan fenomena yang berkembang di lapangan. Data yang diperoleh melalui wawancara ini berupa kondisi fisik sekolah, kegiatan belajar mengajar, kegiatan pengembangan kompetensi guru, aktivitas ekstrakurikuler siswa, dan kendala-kendala dalam pendidikan karakter.

Penelitian ini juga menggunakan teknik dokumen dengan cara membaca buku-buku, catatan harian, dokumen tertulis, peraturan sekolah. Memanfaatkan teknik dokumentasi untuk mengetahui profil sekolah. Data yang terkumpul berupa profil sekolah yakni sarana dan prasarana, tata tertib dan kegiatan pengembangan diri siswa, perangkat pembelajaran yaitu silabus dan rencana pelaksanaan pembelajaran (RPP), serta foto-foto kegiatan pembelajaran baik di dalam kelas maupun diruang kelas.

Langkah selanjutnya yang dilakukan peneliti setelah menentukan teknik pengumpulan data adalah menentukan instrumen pengumpulan data. Adapun instrumen pengumpulan data yang digunakan dalam penelitian ini disesuaikan dengan teknik pengumpulan data yang telah ditentukan, yaitu: (1) pedoman observasi, ini digunakan sebagai alat pengumpulan data yang diperoleh dari hasil observasi yang dicatat dan dikumpulkan untuk kemudian dilakukan analisis lebih lanjut, (2) pedoman wawancara terstruktur dan pedoman wawancara tidak terstruktur atau bebas, ini husus dipergunakan untuk mengumpulkan data yang diperoleh dari hasil wawancara yang dilakukan peneliti saat melakukan pengumpulan data di lapangan, (3) dokumenter, antara lain photo digital dan recorder.

Keabsahan data merupakan hal sangat penting karena penelitian yang baik memerlukan data yang valid, kredibel, dan reliabel. Proses pengujian keabsahan data yang akan dilakukan dalam penelitian ini meliputi:

Trianggulasi, yakni pengecekan data dari beberapa sumber, cara, dan waktu yang berbeda. Penelitian ini menggunakan triangulasi sumber dan teknik. Triangulasi sumber dilakukan dengan cara membandingkan informasi dari satu orang dengan informasi dari orang lain. Hal ini ditujukan untuk melakukan crosscheck informasi dari seseorang yang kadang-kadang bisa karena dipengaruhi oleh kepentingan, subjektivitas, dan lain-lain. Sedangkan triangulasi teknik dilakukan dengan membandingkan infromasi yang diperoleh dari teknik wawancara dan membuktikannya melalui observasi dan dokumentasi. Tujuannya adalah agar informasi yang diberikan tidak sembarangan informasi, tetapi didasarkan pada realitas yang ada.

Perpanjangan pengamatan yaitu kembali ke lapangan untuk melakukan pengamatan dan wawancara dengan responden yang sama maupun responden yang baru dilakukan pada bulan Januari sampai Februari diperpanjang sampai dengan bulan Maret 2012. Hal ini dilakukan untuk menguji apakah fenomena yang ditemukan sebelumnya sama dengan fenomena yang ditemukan sesudahnya mengenai komptensi guru IPS dalam pembelajaran berbasis pendidikan karakter. Dengan langkah ini data penelitian lebih reliabel dan secara psikologi meningkatkan hubungan personal antara peneliti dengan subjek penelitian.

Analisis kasus negatif yaitu peneliti mencari data yang berbeda atau bertentangan dengan data 
yang telah ditemukan. Bila tidak ada data yang berbeda atau bertentangan data yang ditemukan berarti data yang ditemukan sudah dapat dipercaya. Namun apakah ada data yang bertentangan, dan apa bila data bertentangan maka akan dirubah hasil temuannya.

Menggunakan bahan referensi yaitu bukti pendukung dari data-data yang diperoleh peneliti berupa rangkuman hasil wawancara, foto-foto, catatan lapangan dari hasil observasi, dan dokumen-dokumen dari sekolah seperti kurikulum pendidikan, catatan kejadian, format penelitian, dan lain-lain.

Analisis data dalam penelitian kualitatif dilakukan sejak sebelum memasuki lokasi penelitian, selama di lokasi, dan sampai selesai penelitian. Data dari lapangan dianalisis dengan cara direduksi, dirangkum, dan difokuskan pada data penting, tema dan hubungan yang sering terjadi, sehingga kesimpulan itu akan lebih mendasar, kesimpulan yang dibuat harus selalu di verifikasi selama penelitian berlangsung.

Penelitian kualitatif dengan analisis data terfokus selama di lapangan untuk mengumpulkan data di lokasi penelitian adalah (1) analisis sebelum di lapangan adalah analisis dilakukan terhadap data hasil studi pendahuluan atau data sekunder, yang akan digunakan untuk menentukan fokus penelitian, dan (2) analisis data di lapangan adalah analisis data pada saat pengumpulan data di lapangan melalui wawancara dan catatan lapangan, peneliti sudah melakukan analisis terhadap jawaban yang diwawancarai. Sedangkan secara umum analisis data di lapangan dilakukan melalui tahapan sebagai berikut: 1) Mencatat semua temuan di lapangan baik melalui pengamatan wawancara dan dokumentasi dalam bentuk catatan lapangan; 2) Menelaah kembali hasil catatan lapangan, wawancara dan studi dokumentasi, serta memisahkan data yang dianggap penting dan tidak penting, pekerjaan ini di ulangi kembali untuk memeriksa kemungkinan klasifikasi; 3) Mendiskripsikan data yang telah diklasifikasi untuk kepentingan penelahan lebih lanjut dengan memperhatikan fokus dan tujuan penelitian.; 4) Membuat analisis akhir dengan melihat hasil reduksi data dan tetap mengacu pada rumusan masalah serta tujuan yang hendak dicapai. Data yang telah tersusun tersebut dihubungkan dan dibandingkan antara satu dengan yang lainnya sehingga mudah ditarik analisis sebagai jawaban dari permasalahan yang ada.

\section{Hasil Penelitian dan Pembahasan}

Adapun hasil penelitian kompeten guru ips dalam pembelajaran berbasis pendidikan karakter di SMP Muhammadiyah Kota Ternate yakni: (1) untuk mengetahui kompetensi guru IPS dalam melaksanakan pendidikan karakter secara terintegrasi dalam pembelajaran IPS, (2) untuk mengetahui kompotensi guru IPS dalam menerapkan berbagai metode pembelajara untuk pendidikan karakter di SMP Muhammadiya 1 dan SMP Muhammadiyah 2 kota ternate, (3)dan sekaligus mengetahui kendala yang dihadapi oleh guru dalam melaksanakan pendidikan karakter.

Gambaran umum SMP 1 Muhammadiyah dan SMP 2 Muhammadiyah kota ternate, di SMP Muhammadiyah 1 Kota Ternate didirikan atas tanah seluas $4.500 \mathrm{~m} 2$, di lingkungan sekolah terdapat perkampungan yaitu sebelah utara sekolah terdapat Kelurahan Bastiong, sebelah selatan Kelurahan Falajawa dua, sebelah barat pekuburan perbatasan Kelurahan Bastiong dan Kelurahan Ubo-ubo, sebelah timur kelurahan Bastiong yang masuk dalam lokasi SMP Muhamadiyah 1 Kota Ternate (Dokumen sekolah).

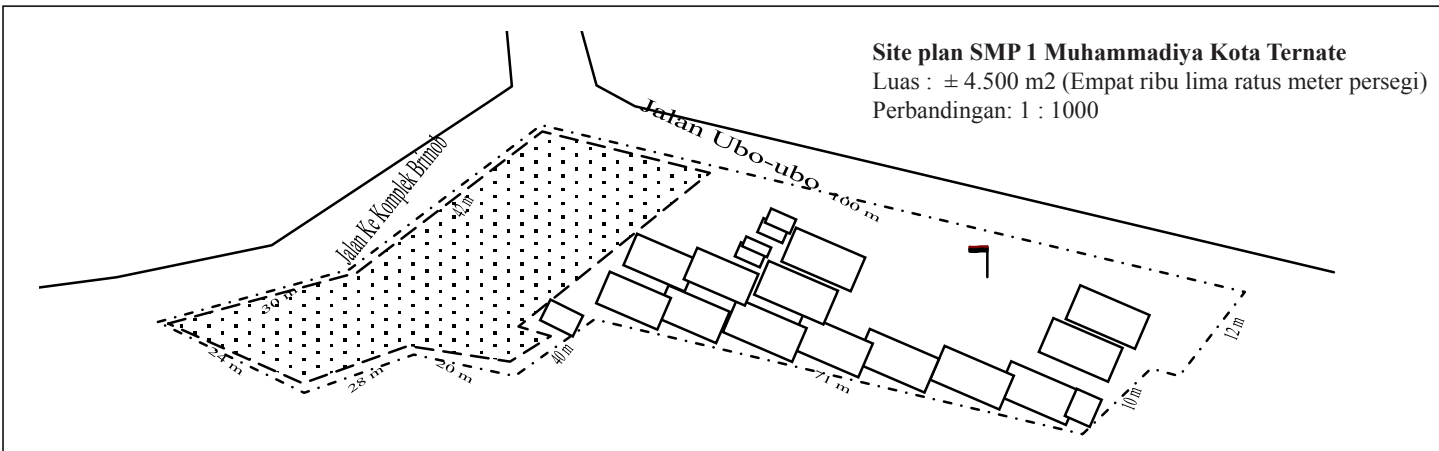

Gambar 1. Site plan SMP 1 Muhammadiya Kota Ternate 
Site Plan SMP Muhammadiyah 1 Kota Ternate

Sumber: Dokumen Sekolah

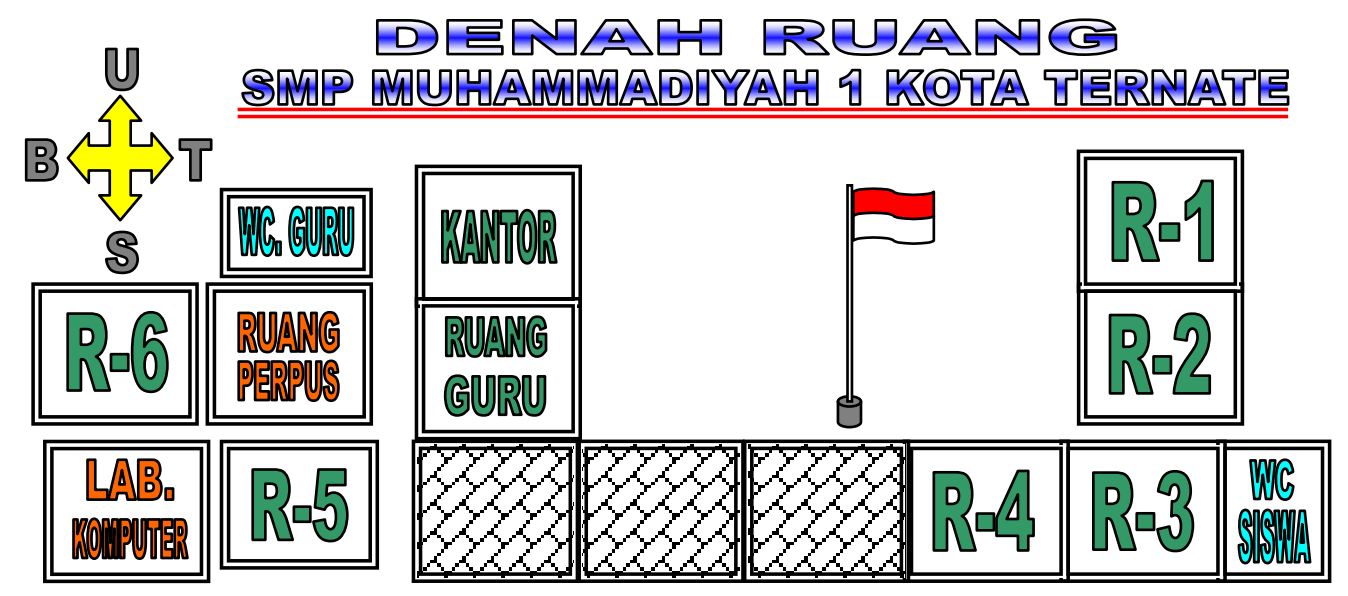
Keterangan :
1. Kantor
2. Ruang Guru
4. Lab
7. MCK
10. Rm. Penjaga Sekolah
3. Ruang Kelas
5. Mushalla
8. Dapur
6. Perpus
9. Tempat Wudhu

Gambar 2. Denah SMP Muhammadiyah 1 Kota Ternate

Lokasi SMP Muhammdaiyah 2 Kota Ternate terletak di jalan batu Angus Ternate Utara di kelurahan Sulamadaha di ujung kota Ternate. Suasana di sekolah ini nyaman dan udaranya sejuk.

Jumlah guru di SMP Muhammadiyah 2 Kota Ternate sebayank 16 orang dengan kualifikasi sarjana (SI) dengan berbagai latar pendidikan yang beragam dan 450 peserta didik untuk tahun ajaran 2008/2009, setiap dua minggu sekali sekolah bekerja sama dengan KODIM Ternate untuk pengembangan karakter anak. Di samping itu guna meningkatkan kebersamaan dan kualitas guru dan siswa. SMP Muhammadiyah 2 kota Ternate sebagai salah satu sekolah pembinaan karakter oleh KODIM, dalam bentuk pembinaannya adalah melalui kegiatan ekstrakurikuler, dimana semua peserta didik diwajibkan mengikuti kegiatan tersebut. Untuk mengetahui jumlah siswa bisa dilihat tabel di bawah ini:

Tabel 1. Jumlah siswa SMP Muhammadiyah 2 Kota Ternate

\begin{tabular}{|c|c|c|c|c|c|c|c|c|c|}
\hline \multirow{2}{*}{$\begin{array}{c}\text { Thn } \\
\text { Pelajaran }\end{array}$} & \multirow{2}{*}{$\begin{array}{c}\text { Jlh } \\
\text { Pendaftar } \\
\text { (Calon } \\
\text { Peserta } \\
\text { didik baru) } \\
\end{array}$} & \multicolumn{2}{|c|}{ Kelas I } & \multicolumn{2}{|c|}{ Kelas II } & \multicolumn{2}{|c|}{ Kelas III } & \multicolumn{2}{|c|}{$\begin{array}{c}\text { Jumlah } \\
\text { (kls I + II + III) }\end{array}$} \\
\hline & & $\begin{array}{c}\text { Jml } \\
\text { peserta } \\
\text { didik }\end{array}$ & $\begin{array}{c}\text { Jml } \\
\text { rombel }\end{array}$ & $\begin{array}{c}\text { Jml } \\
\text { peserta } \\
\text { didik }\end{array}$ & $\begin{array}{c}\text { Jml } \\
\text { rombel }\end{array}$ & $\begin{array}{c}\text { Jml } \\
\text { peserta } \\
\text { didik }\end{array}$ & $\begin{array}{c}\text { Jml } \\
\text { rombel }\end{array}$ & $\begin{array}{c}\text { Peserta } \\
\text { Didik }\end{array}$ & Rombel \\
\hline $2005 / 2006$ & 25 & 25 & 1 & 30 & 1 & 29 & 1 & 84 & 3 \\
\hline $2005 / 2006$ & 30 & 30 & 1 & 25 & 1 & 20 & 1 & 85 & 3 \\
\hline $2007 / 2008$ & 54 & 54 & 2 & 30 & 1 & 25 & 1 & 109 & 3 \\
\hline $2008 / 2009$ & 30 & 30 & 1 & 54 & 2 & 30 & 1 & 114 & 4 \\
\hline $2009 / 2010$ & 30 & 30 & 1 & 30 & 1 & 54 & 2 & 114 & 3 \\
\hline $2010 / 2011$ & 20 & 20 & 1 & 30 & 1 & 30 & 1 & 80 & 3 \\
\hline
\end{tabular}

Sumber: dokumen sekolah 
Alat kelengkapan pendidikan sangatlah penting karena tanpa adanya alat kelengkapan ini, kegiatan belajar mengajar di sekolah tidak dapat terlaksana dengan baik. Salah satu faktor pendukung proses pembelajaran adalah adanya manajemen kelas yang baik. Manajemen kelas merupakan bagian dari pengelolaan sekolah seperti halnya pengelolaan guru, peserta didik, sarana dan prasarana, peningkatan tata tertib/ disiplin. Hal ini didasarkan pada suatu pendapat bahwa pendukung utama tercapainya tujuan pembelajaran adalah kelas yang baik dalam arti seluas-luasnya.

Sarana dan prasarana yang dimiliki oleh SMP Muhammadiyah 1, yaitu: ruang multi media, ruang Laboratorium IPA serta Perpustakaan yang representatif begitu pula perangkap komputer walaupun masih kurang dalam menunjang kegiatan belajar pada mata pelajaran IPA, namun secara umum belum lengkap. Ada pun wawancara dengan Bapak Taib guru SMP Muhammadiyah 1

Kota Ternate menjelaskan bahwa:

Persediaan sarana dan prasaran di sekolah kita sudah sejak lama. Oleh karena itu, sudah sebagian tidak bisa dipakai lagi (rusak), padahal sarana dan prasaran sangat penting untuk menunjang kebutuhan siswa di sekolah (wawacara tanggal 12 Februari 2012).

Fasilitas gedung SMP Muhammadiyah 1 Kota Ternate yang ditempati yaitu terdiri dari ruang belajar yang di pakai sebanyak 9 lokal, 1 ruang perpustakaan dengan ukuran $(6 \times 8), 1$ ruang gudang ukuran $(3 \times 2), 2$ buah $\mathrm{km} / \mathrm{wc}$ guru $(2 \times 2)$, $4 \mathrm{~km} /$ wc siswa ukuran $(2 \times 2)$, praktek komputer, 1 ruangan praktek mengetik, dan lainya. (Hasil catatan lapangan). Adapun Jumlah Sarana dan Prasarana SMP Muhammadiya 1 Kota Ternate sebagaimana tabel di bawah ini

Tabel 2. Sarana dan Prasarana SMP Muhammadiyah 1 Kota Ternate

\begin{tabular}{rlcc}
\hline No & Sarana dan Prasarana & Jumlah & Keterangan \\
\hline 1 & Ruangan Kepala Sekolah & 1 Unit & Baik \\
2 & Ruangan Guru & 1 Unit & Baik \\
3 & Ruang Belajar Siswa & 9 Unit & Baik \\
4 & Perpustakaan & 1 Unit & Baik \\
5 & Mading dan Papan Pengumuman & 2 Buah & Baik \\
6 & Masjid & 1 unit & Baik \\
7 & Laboratorium Komputer & 1 Unit & Baik \\
8 & Unit Kegiatan Siswa (UKS) & 1 Unit & Baik \\
9 & Kamar WC Siswa & 4 Unit & Baik \\
10 & Kamar WC Guru & 2 Buah & Baik \\
11 & Dapur & 1 Unit & Baik \\
12 & Gudang & 1 Unit & Baik \\
\hline
\end{tabular}

Sumber: Data Muhammadiyah 2010-2011

Salah satu faktor pendukung proses pembelajaran adalah adanya manajemen kelas yang baik. Manajemen kelas merupakan bagian dari pengelolaan sekolah seperti halnya pengelolaan guru, peserta didik, sarana dan prasarana, peningkatan tata tertib/disiplin. Hal ini didasarkan pada suatu pendapat bahwa pendukung utama tercapainya tujuan pembelajaran adalah kelas yang baik dalam arti seluas-luasnya.

Kelas merupakan wahana pertemuan segala komponen pendidikan. Oleh karena itu, pembinaan pendidikan diarahkan pada kelas dan konsekuensinya amatlah wajar jika dikelola secara baik dan optimal. SMP Muhammadiyah 2 mempunyai 10 ruang kelas belajar yang setiap ruangnya berukuran $6 \times 8 \mathrm{~m}$, dan setiap kelas mempunyai siswa tidak merata, ada yang 20 orang ada yang 23 orang bahkan 30 orang. Setiap kelas memiliki ciri khusus yang berbeda-beda baik segi penataan ruang belajar sampai kompetensi yang dimiliki siswa baik kemampuan 
rendah, sedang maupun tinggi

\section{Simpulan dan Saran}

Simpulan

Kompetensi guru 1PS dalam melaksanakan pembelajaran pendidikan karakter di SMP Muhammadiyah 1 dan 2 Kota Ternate dapat di simpulkan sebagai berikut.

Kompetensi guru IPS di SMP Muhammadiyah 1 dan 2 Kota Ternate dalam melaksanakan pendidikan karakter cenderung rendah (kurang baik). Hal ini disebabkan oleh guru IPS masih kurang memiliki wawasan dasar keilmuan karakter, di samping itu juga guru belum aktif dan kreatif.

Guru IPS di SMP Muhammadiyah 1 dan SMP Muhammadiyah 2 Kota Ternate cenderung menerapkan metode pembelajaran konvensional (ceramah) dengan sedikit sekali metode tanya jawab dan diskusi. Pertanyaanpun sebagaian besar dari guru, bukan dari siswa, Oleh sebab itu siswa merasa bosan mendengarkannya.

Kendala-kendala yang ditemukan dalam pembelajaran pendidikan karakter di SMP Muhammadiyah 1 dan SMP Muhammadiyah 2 Kota Ternate yaitu berasal dari guru yang masih lemah pemahamannya tentang pendidikan karakter, sarana dan prasarana belum memadai, rendahnya kesadaran peserta didik, rendahnya dana dan biaya penunjang dalam pendidikan, media pembelajaran masih terbatas, serta buku-buku penunjang yang digunakan untuk kepentingan proses pembelajaran masih belum memadai.

Implikasi dari kesimpulan di atas dapat dirumuskan bahwa kompetensi guru IPS dalam pendidikan karakter maka kegiatan ekstrakurikuler dan intrakurikuler sebagian guru tidak melibatkan diri. Oleh sebab itu, perlu disusun deskripsi masing-masing kegiatan yang terdiri atas materi kegiatan yang berhiubugan dengan pendidikan karakter, selain itu bentuk pengawasan dan tim penilaiannya. Hal ini apabila guru yang tidak merespon dengan baik akan diketahuinya.

Kegiatan ekstrakurikuler yang harus di kembangkan adalah keterampilan kerajinan sangat cocok untuk pengembangan domain psikomotorik. Kemudian nilai yang dapat diintegrasikan antara lain "kepedulian terhadap lingkungan sekolah". Misalnya kerajinan membuat tempat sampah, membuat sosiru. Kemudian hasil karya tersebut dipraktekkan di sekolah, dipasang pada tempat yang strategis, otomatis akan mendidik semua warga sekolah untuk peduli lingkungan melalui pemilahan sampah.

Kendala-kendala yang dialami pada pelaksanaan pendidikan karakter di SMP Muhammadiyah 1 dan SMP Muhammadiyah 2 Kota Ternate dapat diidentifikasi sebagai berikut:

Guru Belum dapat melaksanakan pendidikan karakter dengan baik, guru IPS belum memiliki wawasan dasar keilmuan karakter. Di samping itu, guru belum aktif dan kreatif, serta memiliki kemauan untuk mengembangkan wawasan pendidikan karakter kedalam mata pelajaran IPS.

Sarana dan prasarana SMP Muhammadiyah 1 dan SMP Muhammadiyah 2 Kota Ternate masih memiliki sejumlah permasalahan di antaranya masalah sarana dan prasarana yang belum lengkap yaitu ruang multimedia, ruang Laboratorium IPA, dan Perpustakaan sekolah yang belum representativ. Begitu pula perangkat komputer yang masih kurang dalam menunjang kegiatan belajar pada mata pelajaran IPA. Ruang kesenian dapat dijadikan daya tarik tersendiri bagi calon siswa baru, tetapi sampai sekarang belum terealisasi di sekolah. Sekolah memiliki fasilitas seperti Mushalla yang masih sederhana dan ruang belajar juga masih terbatas. Sebagai simpulan bahwa sarana dan prasarana belum cukup.

Bagi peserta didik, pendidikan karakter dalam pembelajaran IPS dapat memberi peluang untuk mengembangkan kreativitas akademik, kemampuan analitik, kemampuan asosiatif, dan kemampuan eksploratif serta elaboratif. Tetapi peserta didik belum melaksanakannya secara serius. Selain itu, sebagian siswa yang tidak mengikuti aturan tata tertib sekolahnya.

dana dan pembiayaan selama ini dana yang di perlukan untuk pengembangan sarana dan prasaran seperti tempat pengajian dan pendidikan life skills masih ditanggung oleh sekolah walaupun ada bantuan dana dari pemerintah tetapi jumlahnya sangat kecil. Minimnya dana operasional secara tidak langsung berakibat pada keterlaksanaan program pendidikan karakter tidak optimal dan akan mengalami kemerosotan, demikian pula kelancaran proses penyelenggaraan pendidikan 
di sekolah juga terhambat.

Program Pembelajaran dibutuhkan waktu yang cukup lama untuk dapat melihat hasil dari program pendidikan karakter. Begitu juga dalam proses pembelajaran baik di kelas maupun di luar kelas karena alokasi waktu yang ditentukan dirasa masih kurang khususnya pembelajaran karakter dalam mata pelajaran IPS. Akan tetapi kecil kemungkinan untuk menambah aloksi waktu yang ada sehingga diperlukan kreativitas dan kemampuan melakukan inovasi terhadap metode pembelajaran. Metode mengajar sebagian besar guru yang masih kurang kreatif dan inovatif. Demikian pula pelaksanaan pelajaran yang berhubungan dengan karakter masih rendah, artinya belum semua mata pelajaran mengimplementasikan pendidikan karakter di sekolah.

Pembinaan Karakter belum semua guru atau karyawan mampu menjadi contoh karakter bagi siswanya dan bahkan guru kurang aktif membantu kegiatan pembinaan karakter siswa dalam kegiatan ekstrakurikuler dan intrakurikuler. Beberapa di antaranya bahkan bersikap kontraproduktif dengan tidak memberikan contoh yang semestinya seperti, tidak mengikuti shalat berjamaah di masjid dan tidak mengucapkan salam dan bersalaman, dan lain-lain. Meskipun persentasinya kecil, namun hal ini dapat menghambat pendidikan karakter yang dilakukan oleh teman sejawatnya. Latar belakang karakter siswa sangat bervariasi, maka dibutuhkan perhatian dan kemampuan guru yang bervariasi pula. Budaya malas pada sebagian guru juga sangat menghambat implementasi pendidikan karakter di sekolah. Hasil pengamatan di kelas menunjukkan bahwa guru yang sedang mengajar sama sekali tidak melakukan pembinaan karakter. Guru tersebut mengajarkan materi pelajaran secara monoton dan tidak mengintegrasikan nilai-nilai karakter dalam mata pelajaran. Pengaruh media elektronik khususnya televesi juga dapat menghambat pendidikan karakter siswa.

Kurangnya buku-buku penunjang terutama buku panduan pendidikan karakter, Sedangkan buku lainnya sudah cukup sehingga guru tidak lagi susah-susah mencari buku.
Dengan demikian, perlu dilakukan perencanaan yang matang untuk setiap program, sehingga jelas dalam kegiatan pembelajaran di kelas maupun di luar kelas. Hal ini akan memudahkan pelaksanaannya di lapangan serta membawa hasil yang maksimal. Sekolah harus lebih menyadari bahwa guru IPS adalah tanggung jawab semua warga sekolah, pemerintah, dan pengurus Muhammadiyah Kota Ternate.

Diharapkan, nantinya melalui pendidikan karakter dapat meningkatkan kualitas dalam rangka memelihara kerukunan bangsa, saling hormat menghormati antar pemeluk agama yang berbeda, menghargai sesama teman, disiplin bekerja dan lainnya.Pendidikan karakter mempunyai tempat yang sangat strategis dan penting dalam sistem pendidikan nasional secara keseluruhan, karena pendidikan karakter pada intinya berujung pada pendidikan yang memperbaiki diri manusia itu sendiri.

Saran

Berdasarkan pada kesimpulan, implikasi, dan keterbatasan penelitian, maka dapat durumuskan saran-saran sebagai berikut:

Pemerintah hendaknya memfasilitasi guruguru IPS untuk mengikuti pelatihan-pelatihan yang dapat mengembangkan kreativitas guru dalam pengembangan pembelajaran yang mengintegrasikan pendidikan karakter.

Dalam usaha mengatasi pendidikan karakter siswa di SMP Muhammadiyah 1 dan 2 Kota Ternate, peran warga sekolah, pemerintah kota Ternate dan yayasan Muhammadiyah perlu dilibatkan dalam pembinaan guru untuk meningkatkan kompetensi.

Pihak sekolah agar membentuk tim pengembangan pendidikan karakter secara terprogram.

Seyogyanya guru lebih banyak mempelajari strategi metode pembelajaran, sehingga mampu mengaplikasikan berbagai metode pembelajaran yang menarik.

Sekolah diharapkan lebih memperhatikan pentingnya sarana prasarana pembelajaran IPS, lebih menjadikan dana untuk pengadaan media 
pembelajaran IPS dan buku-buku penunjang pembelajaran IPS.

\section{Daftar Pustaka}

Nursid Sumaatmadja, et al. (2005). Konsep dasar ips. Jakarta: Universitas Terbuka.

Martinis Yamin. (2007). Desain pembelajaran berbasis tingkat satuan pendidikan. Jakarta: Gaung persada press.

E. Mulyasa. (2010). Kurikulum berbasis kompetensi, konsep, karakteristik, dan implementasi. Bandung: Remaja Rosdakarya.

Darmiyati Zuchdi, et al. (2009). Pendidikan karakter, grand desain dan nilai-nilai target. Yogyakarta: UNY Press.

Dharma Kesuma, et al. (2011). Pendidikan karakter, kajian teori dan praktek di sekolah Bandung: Remaja Rosdakarya.

Depdiknas. (2003). Undang-undang RI nomor 20 tahun 2003, tentang sistem pendidikan nasional.

(2005). Undang-undang RI nomor 14 tahun 2005 tentang guru dan dosen. 